\title{
SOLEDAD ACOSTA DE SAMPER: CATOLICISMO Y MODERNIDAD EN COLOMBIA SIGLO XIX
}

\author{
POR \\ William Elvis Plata Quezada ${ }^{1}$ \\ Universidad Industrial de Santander, Bucaramanga, Colombia
}

\begin{abstract}
RESUMEN
Soledad Acosta de Samper (1833-1913) es la principal escritora colombiana del siglo xIX y una de las más importantes de América Latina. Estudiada fundamentalmente por sus aportes a la literatura, su condición religiosa -tema habitual en sus escritos- ha sido poco abordada. Buscando llenar este vacío, el presente texto pretende analizar el pensamiento y la praxis religiosa de Soledad Acosta de Samper, poniendo a prueba la siguiente hipótesis: gracias a su particular educación y condición, ella es, en Colombia, una de las más claras representantes de un catolicismo que trató de conciliar con ideas fundamentales del mundo moderno que no se oponían al Evangelio y a su fe. Todo ello en un contexto de agitación político-religiosa, marcado por la intolerancia y la intransigencia. Busca llamar la atención sobre la necesidad de un estudio detenido y sistemático del catolicismo decimonónico y sus relaciones con el mundo moderno, yendo más allá de las tesis que lo conciben como unísono y monolítico.
\end{abstract}

PALABRAS CLAVE: Soledad Acosta de Samper; Colombia; catolicismo; modernidad; liberalismo; escritoras.

\section{SOLEDAD ACOSTA: CATHOLICISM AND MODERNITY IN COLOMBIA $19^{\text {TH }}$ CENTURY}

\begin{abstract}
Soledad Acosta (1833-1913) is the main Colombian writer of the nineteenth century and the largest in Latin America. She has been mainly studied for his contributions to literature, but their religious aspects usual -Item in his writings have been little addressed. Looking to fill this gap, the present paper attempts to examine religious thought and praxis of Soledad Acosta, testing the following hypothesis: thanks to its special education and status, she is in Colombia, one of the most clear representatives of Catholicism trying to reconcile with fundamental ideas of the modern world that they were not opposed to the Gospel and the Catholic faith. This in a context of political and religious turmoil, marked by intolerance and intransigence. It is intended to draw attention to the need to study systematically and detailed Catholicism of the nineteenth century and its relations with the modern world, to go beyond the thesis unison and view it as monolithic.
\end{abstract}

KEY WORDS: Soledad Acosta; Colombia; Catholicism; modernity; liberalism; writers.

Cómo CITAR ESTE ARTículo / CITATION: Plata Quezada, W. E. 2017. «Soledad Acosta de Samper: catolicismo y modernidad en Colombia siglo XIX». Hispania Sacra 69, 139: 293-305. doi: 10.3989/hs.2017.020

\author{
Recibido/Received 23-02-2015 \\ Aceptado/Accepted $\quad$ 02-03-2016
}

Soledad Acosta de Samper (1833-1913) es para muchos, la principal escritora colombiana del siglo XIX y una de las más importantes de América Latina. Muy prolífica, fue novelista, cuentista, periodista, historiadora y editora. Escribió 21 novelas, 48 cuentos, cuatro obras de teatro, 43 ensayos sobre temas sociales y literarios, y 21 obras de historia; fundó, dirigió y redactó, prácticamente sola, cinco

1 weplataq@uis.edu.co / ORCID iD: http://orcid.org/0000-00016164-1037 periódicos, en su mayoría dirigidos a la mujer; además hizo numerosas traducciones. Olvidada hasta hace apenas unas décadas, los estudiosos de la literatura han contribuido a rescatar su obra literaria para las nuevas generaciones. Sin embargo, el interés de los historiadores por su figura y obra sigue siendo escaso. Es ignorada -además de su contribución a la historiografía- una faceta muy evidente en su obra y accionar: su condición religiosa, su aporte a la Iglesia Católica a la cual perteneció, máxime cuando estuvo casada con alguien que fue liberal radical y después ideólogo del 
proyecto de "Regeneración"2, uno de los políticos más influyentes de la segunda mitad del siglo XIX en Colombia. EI barrido bibliográfico realizado por la teóloga Isabel Corpas de Posada ${ }^{3}$ permite concluir que los acontecimientos históricos que sirven de marco a los escritos de Soledad han sido prácticamente ignorados y que ninguno de los textos producidos hasta ese momento se ha interesado por la dimensión religiosa de esta escritora, a pesar de que ella fue una católica militante y que este era uno de sus principales temas de sus textos. Esta perspectiva no ha sido considerada como original por parte de los estudiosos de la obra de Soledad, tal vez debido a que las posturas predominantemente feministas desde las cuales se analizan sus trabajos han estado acompañadas por ideas que consideran innecesario abordar un tema tan importante para su propia vida, para el país de su tiempo y aun para la época actual.

En las páginas siguientes, atendiendo a la idea propuesta y apenas esbozada por Isabel Corpas en un artículo suyo ${ }^{4}$, haremos un acercamiento al pensamiento y a la praxis religiosa de Soledad Acosta, tratando de comprender la naturaleza y sentido de sus creencias y el ejercicio de conciliación que intentó hacer entre dichas creencias y las nuevas ideas propias del mundo moderno, en una sociedad católica, tradicional y poco tolerante. Para ello tendremos en cuenta fundamentalmente dos momentos de su vida: su juventud (especialmente década de 1950) y su madurez (años 18801890). En la primera, gracias a su diario personal, publicado en $2004^{5}$, tendremos un acercamiento un poco más íntimo sobre lo que ella, veinteañera, pensaba y sentía en torno a la religión y al mundo eclesiástico, en un momento importante del debate político-religioso en Colombia. En un segundo momento, a través de algunas de sus publicaciones, editadas en su madurez, haremos una interpretación, tanto de su pensamiento, como de su accionar consecuente con él, esta vez con la distancia que genera la fuente utilizada: la prensa y la literatura. También se aborda la autobiografía de su esposo, José María Samper, publicada en la década de 1870, con el fin de complementar algunas ideas sobre la naturaleza de la fe que ambos profesaron. Todas las fuentes se leyeron siempre buscando contextualizar los textos con los acontecimientos en que se enmarcaron, tanto personales, como sociales, políticos y religiosos. La lógica de lectura está también orientada por la idea de la existencia de corrientes político-religiosas al interior del catolicismo, motivadas por las relaciones Iglesia Católica - mundo moderno que en el siglo XIX generó relaciones que van de la reacción y a la oposición sistemática e intransigente, a la búsqueda de la conciliación, en distintos niveles.

2 La "Regeneración" (1885-1899) es un período de la historia de Colombia, caracterizado por la configuración de un estado centralista y conservador, que tuvo en la Iglesia Católica a su principal baluarte para el orden ideológico y social. Se llama así, porque siguió a un período de dominio del radicalismo liberal, que había establecido un estado federal y laico, generando graves conflictos con la Iglesia Católica y el partido conservador, que se tradujo en varias guerras civiles. Muchos de los creadores del nuevo régimen eran antiguos liberales radicales, desengañados. Se buscaba entonces "regenerar" el país, tras un período -considerado por ellos- como "catastrófico". En lo que respecta a la configuración del Estado, al orden territorial y jurídico, Regeneración estableció las bases de la actual configuración política colombiana.

3 Corpas de Posada 2010.

4 Corpas de Posada 2013.

5 Acosta de Samper 2004.
Se trata apenas de un primer acercamiento, que busca llamar la atención a los investigadores de la historia de la literatura colombiana y latinoamericana del siglo XIX, y del catolicismo de esta época, sobre el rol que pensadores notables como doña Soledad tuvieron en la recomposición de las relaciones catolicismo - mundo moderno, en esta agitada época de la historia.

Soledad Acosta de Samper. Daguerrotipo, 1880

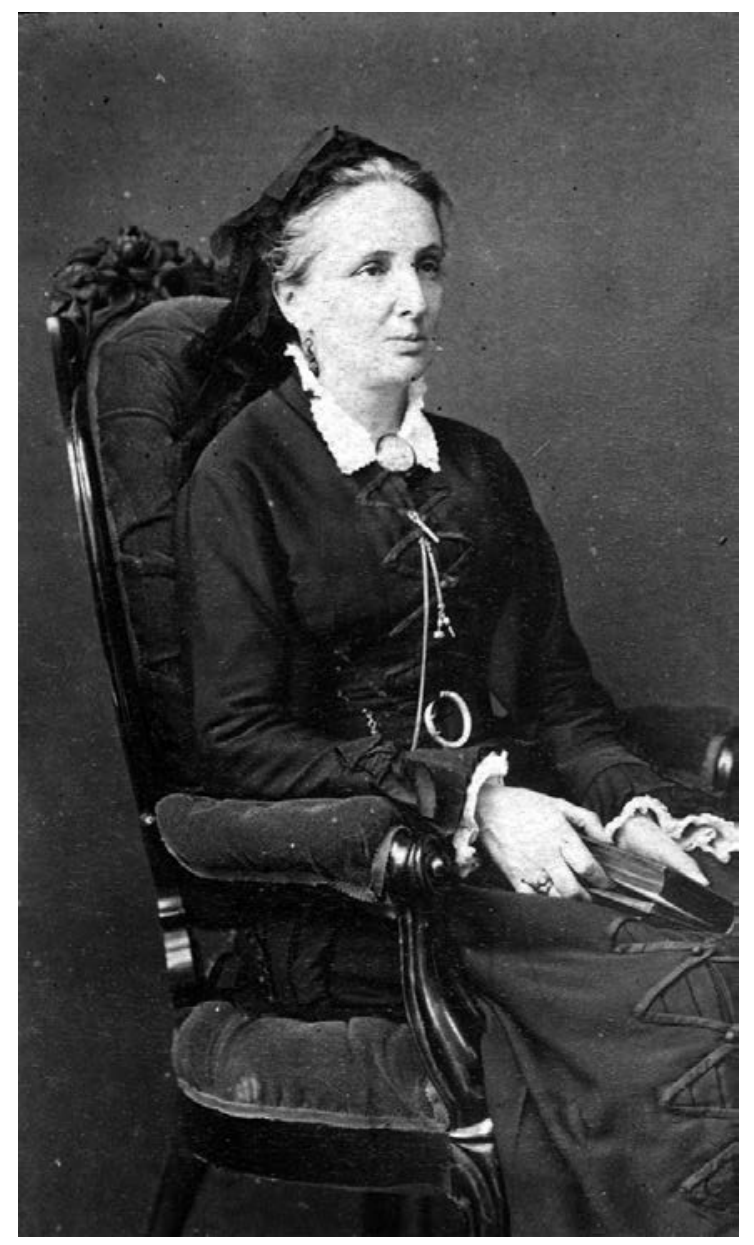

\section{SUS RAZONES PARA CREER}

Soledad Acosta era hija de un matrimonio mixto: su madre, Carolina Kemble, anglosajona, criada en Halifax, Canadá, era anglicana. De formación ilustrada, transmitió a su hija valores como el individualismo, el análisis racional de las cosas, el abstenerse de manifestar públicamente los sentimientos, la continencia y una moral victoriana. También le enseñó el idioma inglés como lengua materna, que compartía con el castellano. De igual manera, su padre, el Coronel Joaquín Acosta, hijo de un español que había llegado a la Nueva Granada en 1767 buscando fortuna, había sido un ferviente patriota y un principal colaborador de los gobiernos republicanos durante la primera mitad del siglo XIX. Además fue escritor y transmitió a Soledad el amor por la lectura y la escritura. Tenía además la costumbre de acoger a los visitantes ilustres -especialmente extranjeros- en su casa de Guaduas, ubicada en el camino entre Honda y Bogotá, de modo que su nombre es mencionado positivamente en 
muchos relatos de viajes que dichos viajeros escribieron. La presencia de extranjeros europeos y norteamericanos en su casa, junto con una cultura ilustrada, muy especial y distinta de lo que recibía una mujer de su época y condición, evidentemente calaron profundamente en ella.

Esta particularidad de su educación incluyó también el factor religioso. Su madre pertenecía a la iglesia anglicana -en ese momento, más cercana que ahora al protestantismo ${ }^{6}$ - mientras que su padre era de tradición católica hispánica. Sin embargo, doña Carolina permitió que su hija se educara en la religión de su padre. Esto se hizo de atendiendo a las conveniencias sociales del momento: era dificil que en la Nueva Granada del siglo XIX, se considerara a una mujer como alguien respetable si no era miembro de la Iglesia Católica ${ }^{7}$.

Su infancia la pasó entre Guaduas y Bogotá. A los doce años viajó con su madre a casa de la abuela materna en Halifax, Nueva Escocia (Canadá). Allí vivió casi un año. Durante ese tiempo recibió una influencia de la cultura protestante a la cual pertenecía su abuela, cultura que va a marcar en parte su vida, especialmente en lo que se refiere a una visión positiva del mundo anglosajón y a una ética victoriana que se infundirá en las élites de nuestros países en la segunda mitad del siglo XIX. Un año más tarde viajó a París y estudió en dos colegios católicos de la ciudad, donde, en 1848 , Soledad hizo su primera comunión. ${ }^{8}$

La educación religiosa de Soledad se hizo, además, a través de las lecturas. Un personaje que influyó mucho en ella fue René de Chateaubriand (1768-1848), conocido por ser uno de los exponentes del romanticismo francés, pero además, uno de los primeros "conciliacionistas", es decir, que intentaron entablar un diálogo entre el mundo moderno y el cristianismo, o dar un espacio a la fe en el mundo moderno. ${ }^{9}$ Por eso lo llamaron "defensor del cristianismo", epíteto que Soledad repite en su diario. ${ }^{10}$

Estando en París, durante su adolescencia, Soledad optó por mantenerse en la Iglesia católica. En su diario íntimo cuenta por qué lo decidió, a pesar de sus antecedentes protestantes familiares. Según ella, fue algo personal. A diferencia de la mayoría de sus congéneres neogranadinas, ella no fue católica por costumbre o tradición sino por decisión y convicción, tras un cuidadoso estudio de las doctrinas de fe:

$6 \quad$ A partir del movimiento de Oxford (1833-1845) se genera una actitud de valoración positiva de ciertos elementos de la Iglesia Católica, como la sucesión apostólica y la liturgia; por ello se buscó una vía media entre catolicismo y protestantismo. Tras dicho movimiento la Iglesia Anglicana, más en su liturgia que en su doctrina, adquiere rasgos cercanos al catolicismo.

El protestantismo (la Iglesia Presbiteriana) sólo hizo su arribo oficial a Colombia, a instancias del gobierno liberal, en 1855. A pesar de su limitada acción -concentrada en extranjeros y algunas élites liberales-su presencia generó gran polémica y muchas acciones intolerantes de parte del clero católico, que hizo sentir por todos los medios, el poder y hegemonía de la Iglesia Católica: Rodríguez 2004.

\section{VV. AA. 1914.}

9 Bénichou 1984: 99-100

10 Acosta de Samper 2004: 296. Tras la Revolución Francesa y ante la progresiva implantación de instituciones e ideas modernas, en el catolicismo se dio un largo debate interno sobre cómo abordar dichos cambios. Las posturas oscilaron entre la confrontación abierta, anclados en la tradición y en las posturas tradicionalistas, y la búsqueda de una conciliación. Quienes le apostaron a esta vía fueron llamados en Francia "conciliacionistas" y sufrieron tanto la condena interna por parte de los tradicionalistas (que contaban con el apoyo del papado) como la crítica externad de liberales y socialistas. Véase además Aubert 1974.
Yo no soy fanática pero soy profundamente religiosa y creo que la [religión] que yo he escogido es la mejor para adorar a Dios. Yo no soy católica sin haber reflexionado mucho sobre esto... Hasta los doce años viví en Bogotá, después fuimos a vivir diez meses con la Madre de mi mamá, que era protestante. Ella trató de convertirme. Mientras estuve allí no leí más sino libros protestantes, ni iba sino a iglesias protestantes. Pero, aunque muy niña, escuchaba todo, leía todo, nunca contradecía, pero no me pude convencer. En Francia estudié y comparé los dos cultos, el Católico y el Protestante, y estoy hondamente convencida que el primero es mejor para mí, porque yo creo que la religión de cada uno se encuentra en el fondo de su corazón y en lo que puede creer. $^{11}$

Otro elemento que marcó su personalidad y religiosidad fue el estilo de crianza, signada por la ociosidad y el aburrimiento, que solo disipaban sus lecturas, a la que se entregaba con pasión. Además, mantuvo relaciones difíciles con su madre. Tal estilo de vida cultivó en ella una personalidad reservada, que gustaba de la soledad (haciendo así honor a su nombre) y proclive al romanticismo. De hecho, sus congéneres la consideraban "melancólica" y reservada. ${ }^{12}$

Dada su personalidad, pareciera que el misterio de la muerte ejerció mucho impacto en la definición y sentido que le otorgó a la religión, al punto de convertirse en aliciente para creer, para alimentar su fe. En su diario íntimo se encuentran varias observaciones en torno a la muerte que dan a entender cuánto le aterraba y le angustiaba ese evento. Lo consideraba un acontecimiento clave en la vida humana, y la llevaba a meditar sobre los afanes de este mundo, los deseos de poder, la ingratitud humana, la razón de la vida y la necesidad de creer. Tal temor, y a la vez fascinación por la muerte, había nacido en ella en torno de los diecinueve años, cuando la Fría Señora pasó por su propia casa, llevándose a su padre Joaquín. ${ }^{13}$ Desde entonces, y en los años que vinieron, Soledad tuvo muy en cuenta este misterioso acontecimiento, relacionándolo con el objeto de vivir y la razón de tener fe. ${ }^{14} \mathrm{~A}$ Soledad le causaban profundo temor y respeto los cementerios y los lugares lúgubres. En enero de 1854, en su diario, sin aparente motivo, disertó al respeto. Tenía muy claro que hoy podría estar viva y mañana no, y que, por tanto, planificar tanto no tenía mayor sentido, al igual que mantener sentimientos tales como el orgullo o el poder. ¿Para qué todo eso, si la muerte puede borrarlo de un tajo ${ }^{15}$

Ciertamente, Soledad temía al olvido y al abandono, a que el tiempo disipara el recuerdo de alguien que pasó por este mundo, de alguien que amó, sufrió, se afanó. Y qué premonitorios eran sus pensamientos, cuando tras su muerte y por muchos años, ella misma permaneció en el olvido de la mayoría de los colombianos ${ }^{16}$.

11 Acosta de Samper 2004. Ibídem: 503.

12 Ibídem: 106-107

13 Ibídem: 106

14 Ídem.

15 Ibídem: 119-120.

16 Recuerdo que reflexioné sobre esto un día de junio de 1995, cuando fui al cementerio central de Bogotá, donde se encuentra su tumba, y la vi en total abandono y deterioro, con la lápida resquebrajada, oculta entre las demás. Aquella que le temía al olvido fue víctima de este, durante mucho tiempo. Afortunadamente, las cosas han ido cambiando. 
Tumba de Soledad Acosta de Samper. Cementerio Central, Bogotá, junio de 1995 (Foto del autor)

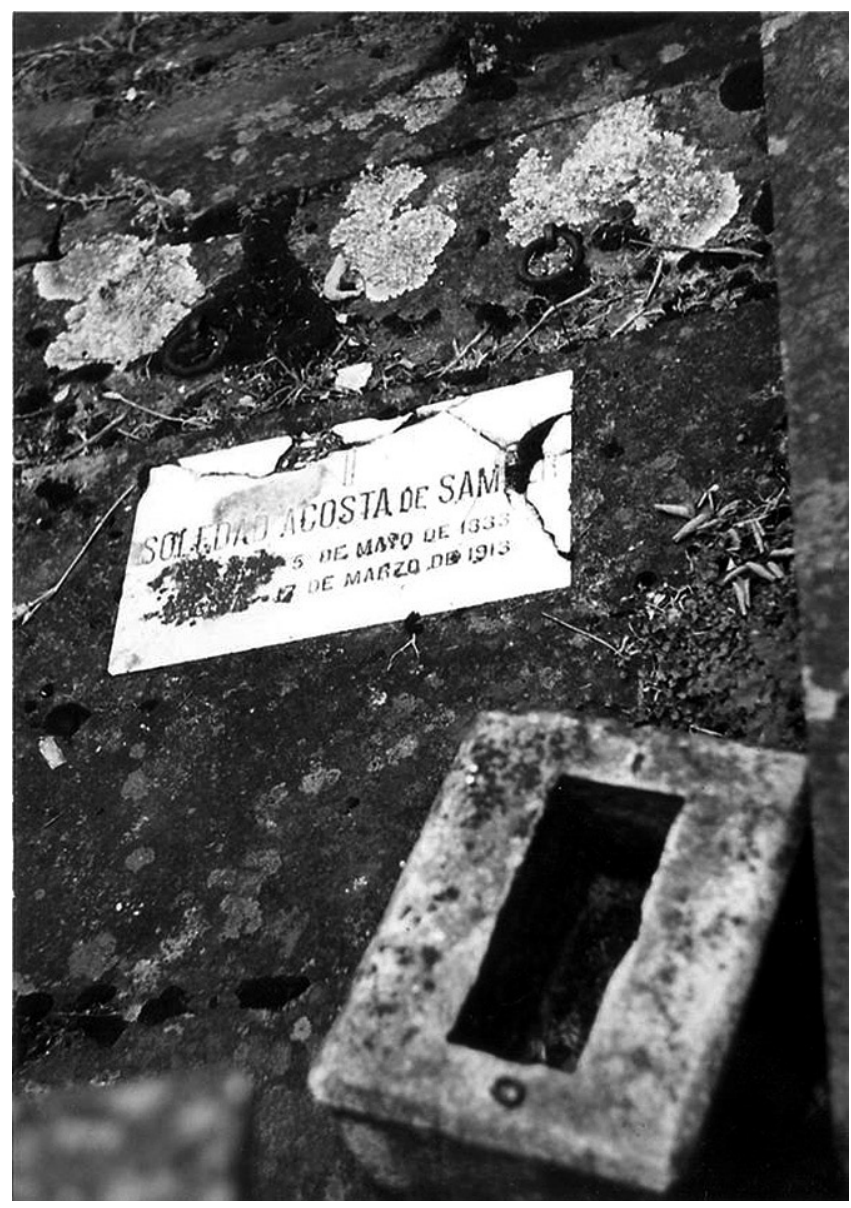

SU FE

De acuerdo con su formación literaria y su espíritu romántico-racional, la creencia en Dios debía apoyarse también en la lógica y la razón. Por eso le interesa la filosofía, la que concebía como un camino para comprender a Dios. Eso quiere decir que no renunciaba al diálogo fe-razón, tema en el cual ya se habían generado enormes zanjas, y que en el siglo XIX estaba generando grandes opositores, basados en doctrinas materialistas. Para Soledad, la filosofía debía partir de la observación de la realidad, de la creación, de la naturaleza. En ella veía la "sabiduría de Dios". ${ }^{17} \mathrm{Sin}$ embargo, aproximándose a lo que afirmaban grandes teólogos como San Agustín de Hipona y Guillermo de Ockham, concebía que la naturaleza humana era demasiado material para poder comprender al Dios del universo, que toda inteligencia tenía sus límites y que «nunca alcanzará el hombre más sino a amar al Señor». Adorar su grandeza, admirar su esperanza. ${ }^{18}$

La creencia en Dios era necesaria para poder tener esperanza, ante un mundo caracterizado por la banalidad, los odios, la absurda guerra, que afectaban a su país por entonces. En 1854, en momentos de una gran agitación política producto de la confrontación entre el régimen del General

\footnotetext{
17 Ibídem: 249

18 ídem.
}

Melo y la alianza entre liberales y conservadores, ${ }^{19}$ Soledad decía:

El genio de la maldad no está quieto. En los bosques el lobo busca su presa. En las ciudades las conspiraciones se traman y los asesinatos se perpetúan. iLlora Virgen del Cielo! iLlora!. jEl rocío es tu llanto celestial! El mundo es un engaño... tú, dulce luna, sigues serena en tu camino, hacia el ocaso pero siempre lloras las maldades de la tierra... ¡Oh!, sí, todo en la tierra es un engaño. ${ }^{20}$

Porque aquel que no abriga en su corazón alguna esperanza siempre, es porque no tiene fe en el Señor que nos guía siempre por la vía que debemos llevar. Poned tus ojos mortales en la esperanza de la inmortalidad, llevad por piloto a la virtud, y por compañera a la bella esperanza y dejad que el viento y las borrascas sacudan tu débil barca, que nunca naufragarás. ${ }^{21}$

La creencia en Dios también se sustentaba en que El no solamente ofrecía una inmortalidad venturosa al hombre, sino que también podía ofrecer felicidad en este mundo: el amor era la clave. Aún desde el amor humano. Eso lo descubrió a los veintiún años, cuando se comprometió en matrimonio con José María Samper. ${ }^{22}$ Así, y paradójicamente, la creencia de Soledad en Dios se amparaba también en el amor que sentía por un político y periodista liberal, masón, librepensador y promotor de algunas de las leyes que escandalizaron y perjudicaron al clero neogranadino de la época.

Ahora bien, esta imagen de Dios, basada tanto en la decepción que sentía ella por este mundo como en las promesas de felicidad del más allá, generaba también un concepto de divinidad que se revestía de justicia. Si el mundo construido por los hombres era un caos, debía existir justicia más allá de él. ${ }^{23}$ Por todo ello, Soledad concebía terriblemente angustioso y desesperanzador el ateísmo. Como uno de los pilares que sostenía la fe de Soledad era el temor a la muerte, por eso un ateo le parecía un ser desgraciado:

¡Que horribles deben ser los pensamientos de un ateo, iviviendo sin esperanza de una vida futura! Feliz, si ha tenido virtud, porque no consiste la bondad en rezar palabras inventadas por otros: los sentimientos de uno no pueden ser iguales a los de los otros. Se puede tener más o menos fervor, más o menos frialdad, y entonces no vienen bien los sentimientos de otros; cuántos habrá que se creen virtuosos, buenos, pero oigamos sus ideas verdaderas y no las que profesan y tal vez nos horrorizaríamos, y otros que se creen ligeros, locos malos; oigamos lo que piensan, y tal vez encontraríamos un alma pura y una conciencia sin mancha. ¡Esta es la vida y estos los hombres! Rousseau dijo: '¿Adónde viste a Dios? No solamente en el universo

19 En abril de 1854 el general José María Melo dio un golpe de estado contra el régimen constitucional liberal. Entre abril y diciembre de ese año, Melo, con el apoyo de las llamadas sociedades democráticas de Artesanos, desengañadas por las promesas incumplidas de los liberales, intentó establecer un régimen de carácter popular, nacionalista y proteccionista en materia económica. Este régimen recibió el rechazo de las elites bogotanas, tanto liberales como conservadoras, al igual que del alto clero. De manera que, aquellos que unos meses antes se atacaban e injuriaban entre sí, se unieron para contraatacar al régimen, venciendo al cabo de ocho meses. Véase Vargas Martínez 1972: 61-77.

20 Acosta de Samper 2004: 387.

21 Ibídem: 270.

22 Ibídem: 530. Se refiere a José María Samper.

23 "El corazón de la mujer. Ensayos psicológicos", en Acosta de Samper 1988: 213. 
que se conmueve, sino en el pájaro que vuela, en la piedra que cae, en la hoja que lleva el viento'. ${ }^{24}$

Puede notarse que, sin embargo, Soledad no condenaba al ateo. Como buena católica, sabía que por las obras debían ser juzgados los hombres, no por sus creencias. Sin duda trataba, además, de disculpar a Samper, que era calificado por muchos como "impío" por sus palabras y actitudes librepensadoras y anticlericales. A Soledad, defensora de la libertad del individuo, del ser humano y de la historia teleológica, con un propósito y un fin, le horrorizaba cualquier doctrina que implicara la pérdida de ese propósito, de ese fin. El ateísmo y el panteísmo las consideraba doctrinas que coartaban la capacidad del hombre para elegir, planificar, pensar y proyectar su futuro y, sobre todo, que eliminaban toda esperanza y todo propósito a la vida humana. Eso le horrorizaba, a juzgar por su diario.

Para Soledad, el nivel de civilización humana crecía y se magnificaba en la medida que tuviera en cuenta la dimensión espiritual. El progreso técnico, la "cultura" y todos los adelantos científicos no significaban nada si se abandonaba a Dios y a la moral cristiana. En un escrito suyo (publicado dos veces) imaginó a los habitantes de una Bogotá futura (año 2000) que habiendo abandonado los principios cristianos, vivían en el egoísmo y la autorreferencia. Así, como narradora de la historia, concluía:

Quitad al hombre el amor a la Divina Providencia, el temor a su ira santa, y el egoísmo se hará dueño de su alma y de su corazón; entonces la noción del Yo, convertida en adoración a sí mismo, hará que ese ser espiritual se convierta en un bruto con instintos de tal..$^{25}$

Con el tiempo, Soledad llegó a la conclusión de que el sentimiento religioso era algo fundamental en la vida de la mujer. En sus publicaciones afirmó que una mujer debía ser creyente y mostrar altos sentimientos religiosos. "La conducta de Margarita es santa y buena, y provino de una idea elevada de sus deberes. iUna mujer sin creencias es una triste cosa!», ${ }^{26}$ decía en uno de sus relatos. En su periódico "La Mujer", consideraba que ellas estaban "naturalmente" inclinadas hacia la religión. ${ }^{27}$ Las mujeres eran las que sostenían o arruinaban los hogares, según sus costumbres, moral y comportamiento religioso. Por ello, debían tener una sólida formación religiosa, dándole importancia al estudio de la Biblia, de manera que pudiera dar razón de su fe. Este punto es importante, pues Soledad consideraba la necesidad de una mujer católica instruida por encima de una mujer piadosa. El estudio de los fundamentos de la fe, con ayuda de la Biblia, permitiría en la mujer la capacidad de dar razón de sus creencias, de la moral y de las virtudes que practicaba. Soledad Acosta iba más allá al considerar a la mujer la salvaguarda de la religión y la moral social. En su revista La Mujer, ya cerrando la década de 1878, afirmaba que si la mujer mantenía sus principios religiosos, la sociedad no correría "peligro" de ser "contaminada" por las ideologías socialistas, anarquistas y otras que para ella buscaban la disolución de las estructuras tradicionales y del orden, y

\footnotetext{
24 Acosta de Samper 2004: 21.

25 Acosta de Samper 2001.

Acosta de Samper 1988: 212.

Acosa de Samper 1878a: 125
}

a las cuales temía en grado sumo. ${ }^{28}$ De esta forma, proporcionar sólidos cimientos religiosos a la mujer era también un asunto de estabilidad y orden social y hasta nacional.

La importancia concedida a la mujer como salvaguarda de la fe fue muy bien vista por el clero y la institución eclesiástica, que justamente por esa misma época, dentro del proyecto de romanización de la Iglesia promocionaba a la familia como "iglesia doméstica", como lugar clave para la conservación y reproducción del sistema religioso, para lo cual necesitaba de la mujer como protagonista. ${ }^{29}$

\section{SU IGLESIA}

La Iglesia católica en la Colombia del siglo XIX no se caracterizaba por ser modelo de orden y estabilidad. De hecho, los años que siguen a la Independencia de España (1810) y hasta el inicio del período Radical (1863) puede considerase como la época más crítica vivida por la institución eclesiástica colombiana en su historia. Durante unos veinticinco años (1810-1835) no hubo relaciones con la Santa Sede, faltaban obispos, la disciplina eclesiástica colapsó y los seminarios desaparecieron. Mientras tanto, el gobierno republicano mantuvo el Patronato y a través de este buscó acabar con las comunidades religiosas conventuales y manejar a su acomodo al clero secular. Luego, a partir de 1835, con una generación de obispos nombrados por el propio gobierno, pero de tendencia ultramontana, empezó un proceso de reorganización eclesiástica que tuvo, sin embargo, muchos tropiezos, especialmente por la situación política: las frecuentes guerras civiles (unas nueve de carácter nacional y otras más de tipo regional) las medidas anticlericales de los gobiernos liberales ${ }^{30}$ y la politización del clero a favor del partido conservador. ${ }^{31}$ También por las divisiones internas (incluyendo de los obispos), la indisciplina y la falta de medios reales para imponer la autoridad episcopal al clero que vivía en pocas parroquias dispersas y mal comunicadas a lo largo y ancho de un país con más de $1.300 .000 \mathrm{~km}^{2}$ y atravesado por tres cordilleras. Lo cierto es que solo con el advenimiento de la Regeneración, en 1886, la Institución eclesiástica colombiana pareció estabilizarse, unificar criterios (en torno a doctrinas tradicionalistas e intransigentes) y estructurarse en torno a los dictámenes emanados por Roma.

En su juventud, Soledad ya era consciente del tipo de iglesia a la cual pertenecía, conocía las irregulares cualidades morales de un clero de formación mediocre. En su diario personal se refirió a un sacerdote de apellido Cuervo, que tenía un huerto y se dedicaba con esmero a su cuidado; Soledad lo llama "bueno y estudioso". ${ }^{32}$ Ese era su ideal de

\footnotetext{
28 Ibídem: 125.

29 Aristizábal 2005.

30 En 1851 y 1861 se expulsa a los Jesuitas, en 1853 se declara el matrimonio civil (y la separación Iglesia y Estado, que no se respetó) y finalmente en 1861-1863 se decreta la tuición de cultos, la expropiación de bienes eclesiásticos y la supresión de todas las comunidades religiosas de ambos sexos.

31 Los dos partidos políticos tradicionales, Liberal y Conservador, nacen en 1848 y 1849 respectivamente. La mayor parte del clero católico pronto se alineó a favor del segundo, que desde un comienzo manifestó sus intenciones de amparar el Estado en la Iglesia Católica, y servirse de ella como elemento para la construcción de la nación.
}

32 Acosta 2004: 184. 
sacerdote, el de hombre ilustrado, amante de la lectura, con alma científica y estudioso. A continuación sentencia: «desgraciadamente es una de las pocas excepciones de virtud verdadera que tenemos en el país entre los ministros de Dios». ${ }^{33}$ Más adelante en su diario, añade algo sobre su concepción del sacerdote:

Yo nunca veo en los sacerdotes a los hombres, solo veo en ellos el instrumento de Dios para servir su altar en nombre del pueblo y para recordarnos los preceptos de la Palabra del Señor. Por eso creo que se debe respetar no a ellos, sino a su Santa Misión. ${ }^{34}$

Sabía cuál era el contexto de los sacerdotes de su medio y época. Quizá había escuchado desde niña, de parte de su madre, críticas a la Iglesia Católica y al clero en particular, pues, como es sabido, este es el sector generalmente más cuestionado por el protestantismo. Seguramente desaprobaba la actitud comprometida en política y hasta fanática de muchos de ellos, coincidiendo con José María Samper; pero ella había logrado separar el "ministerio" del "hombre". Ella respetaba el ministerio sacerdotal y por ende a quien lo ejercía. Su apoyo al catolicismo no estaba basado en el ejemplo del clero. De ser así, seguramente no habría sido católica. Ella considera en la Iglesia un elemento sobrenatural, más allá de la dimensión institucional, que dejaba mucho que desear.

Soledad desde su juventud respetaba los preceptos y costumbres religiosas, aquellas socialmente difundidas y aceptadas. Refiriéndose a un intento de robo realizado en algunas casas el Viernes Santo de 1854, comentaba: «iQué maldad!, jel Viernes Santo, día venerado por toda la Cristiandad! iY este pueblo está tan desmoralizado que ya no respeta ni los días más solemnes de la religión! ¡Así acabó la Semana Santa!».35

Soledad Acosta, por otra parte, al parecer no era muy "piadosa" en el sentido que se entendía en la época. Asistía a las misas dominicales y a las ceremonias de Semana Santa y festividades religiosas, como sus congéneres. Pero, al menos en su diario, no se alude a prácticas como asistir a misa diaria, rezar el rosario o hacer algún tipo de práctica religiosa privada fuera de aquellas de naturaleza pública. "Yo no soy fanática, pero soy profundamente religiosa», afirma en su diario. ${ }^{36}$ ¿Qué era ser considerado fanático en esa época? Este término fue empleado indiscriminadamente a lo largo del siglo, teniendo varias acepciones. Para unos, significaba cualquier tipo de acto religioso vinculado a tradiciones de origen barroco-popular: demostraciones públicas dramáticas de piedad, iconolatría, prácticas penitenciales dolorosas, sacrificios, largos rezos, y en general casi todo lo que se relacionara con la piedad popular. En el ámbito político también se solía emplear el término "fanático" para aludir a sacerdotes o laicos muy comprometidos en causas tradicionalistas e intransigentes $y$, en consecuencia, antiliberales. También para calificar a quienes participaban en política en favor de dichas causas. Así, el término llegó a referirse a cualquier elemento, situación o idea que fuera contraria a todo lo guiado por los principios liberales,

\footnotetext{
33 ídem.

34 Ibídem: 503.

35 Ibídem: 202.

36 Ibídem: 503.
}

racionales y modernos, e inclusive, a cualquier elemento o persona que simplemente se les opusiera. ${ }^{37}$

Dado lo anterior, podemos decir que Soledad se enmarcaba dentro de una concepción moderna de la religión, poco interesada por las prácticas religiosas populares, heredadas de la simbiosis entre el barroco y las culturas amerindias y africanas, además de ciertas tradiciones de origen colonial. Era consecuente con una religiosidad sencilla e ilustrada, racional, práctica, baja en emotividad y con poco espacio para lo maravilloso, considerado accesorio e innecesario.

\section{LOS CONVENTOS}

Un aspecto del pensamiento religioso de Soledad que merece ser resaltado es su visión de los conventos y la vida religiosa femenina. En el siglo XIX es creciente, dentro del liberalismo, una posición contraria a las órdenes religiosas y a la vida religiosa -tanto masculina como femenina- de tipo conventual. De hecho, las primeras medidas anticlericales que los gobiernos republicanos tomaron fueron de este tipo: la supresión de conventos menores, acompañada de una campaña de desprestigio contra los conventos y las órdenes religiosas, llevada a cabo en las décadas de 1820, 1830 y 1850 , especialmente. ${ }^{38}$ Esta posición, sustentada en la crítica moral que los Ilustrados franceses del siglo XVIII hicieron a las decadentes órdenes religiosas de ese tiempo, junto con el utilitarismo benthamista, consideraba que conventos y monasterios eran algo "superado" e innecesario para los tiempos modernos. Según Miguel Samper, cuñado de Soledad, estos habían tenido gran "utilidad" en la sociedad colonial, la cual «no brindaba a la mujer otra carrera que la de la maternidad» por lo cual «tenía que abrir asilos a la inocencia, a la debilidad, al desamparo, al entusiasmo del amor divino", ${ }^{39}$ pero la "inexorable" marcha de la sociedad hacia su "perfección" había dictaminado su desaparición. Este pensamiento utilitarista, sin duda, fue uno de los motivos (además del de apoderarse de las riquezas de las comunidades religiosas para nutrir las exiguas arcas del Estado) que influyó en el decreto de extinción de conventos y comunidades religiosas emitido por Tomás Cipriano de Mosquera en 1861 y confirmado por los constituyentes en 1863. No obstante, muchos católicos de tendencia liberal no estaban de acuerdo con la extinción forzosa de la vida conventual, pues para ellos aun prestaba un servicio: el de refugio a la pena femenina, dado que muchas damas todavía buscaban en él un asilo para consolarse y llorar sus desgracias. Y esto era todavía útil, mientras se realizaba el cambio social

37 El término nace y se constituye en los siglos XVII y XVIII. Locke fue uno de los primeros en utilizarlo, pero se difunde y populariza gracias a los ilustrados franceses, que lo utilizaron con frecuencia en sus escritos críticos contra la Iglesia Católica, especialmente sus prácticas barrocas y místicas. Su primer significado fue, entonces, religioso. Para Voltaire, un fanático era «el que tiene éxtasis, visiones, el que toma los sueños por realidades y sus imaginaciones por profecías» y que «pronto podría llegar a matar por el amor de Dios» (Voltaire, 1764. Dictionaire Philosophique, IV. Paris: 110. Citado en Javaloy 1984: 62). Fue solo hasta el siglo XIX que el significado de este término se amplía a otros campos, como la política, naciendo el "fanatismo patriótico" y la relación entre fanatismo e intolerancia: Ibídem: 64-65.

38 Plata 2012, Cap. 5.

39 Samper 1969 [1867] 
anhelado por liberalismo. ${ }^{40} \mathrm{El}$ convento era, entonces, un lugar para personas tristes y desconsoladas, un refugio para el dolor; nada más.

Esta interpretación fue compartida plenamente por Soledad Acosta. Ella, en su diario íntimo, a los veinte años, reflexionó en varias ocasiones sobre la vida conventual, especialmente la femenina. De visita en el convento de San Diego (masculino) lo describía como un lugar triste y a la vez dulce, muy cercano a su carácter melancólico y romántico. Un lugar perfecto para aquellos que se sentían desengañados de la vida. Lugar para gente triste, lugar para gente decepcionada del mundo. ${ }^{41}$ En abril de 1854 Soledad tuvo un acercamiento a la vida conventual femenina, que le ayudó a reforzar sus ideas. Esta experiencia tuvo lugar en el convento de Santa Inés, en Bogotá, en el cual tuvo que residir durante cuatro días junto con otras jóvenes de la alta sociedad, para resguardarse de posibles saqueos y ultrajes por parte de la soldadesca del general José María Melo, quien había tomado el poder de forma dictatorial. Para su sorpresa, encuentra que las celdas de las monjas no eran frías ni desnudas -como las imaginaba- sino habitaciones confortables, con adornos, cuadros, alfombras y hasta criadas personales. "Los balcones están cubiertos de tazas de flores que cuelgan hasta abajo y llevan el perfume de sus fragantes pétalos a la monja en su retiro ${ }^{42}$ escribió. Pero un día, visita el panteón del convento:

Una pieza pequeña en medio de la cual hay un túmulo de bóvedas a donde depositan a las que mueren... Yo dije iqué triste será morir aquí! La monja [que las guiaba] se inclinó. Una lágrima mojó sus párpados y yo vi que sus ojos buscaban las bóvedas vacías. Infeliz, allí contemplabas tú el lugar último a donde quedarán tus restos. ¿Tal vez aquel suspiro sería de arrepentimiento? Hacía apenas dos años que había tomado el velo. ${ }^{43}$

Esta visita al cementerio reforzó la relación que ella hacía del convento femenino con una "tumba". A la monja con la cual paseaba en el convento de Santa Inés la llamó "cándida y virtuosa"

Alma encerrada allí sin esperanzas, ieternamente allí! Horrible, tétrica idea, siempre lo mismo. Viviendo, ver el lugar a donde ha de morir, contemplar la celda a donde vive y expirará, y meditar sobre su misma tumba... isin remedio! Joven todavía, con talento, con una angelical bondad siempre, con un tinte de melancolía. Pobre monja, sin conocer el mundo estás allí. iTal vez aquí [en el mundo, fuera del convento] estarías, si no más feliz, a lo menos harías algún bien a los hombres!.... iSin embargo estas instituciones las defiendo yo! Si hay algunas que no debían estar allí, hay también otras que en el mundo no estarían contentas. ${ }^{44}$

A continuación hace un elogio a la monja que las guiaba, joven todavía, que llevaba en el convento desde su niñez y que se desempeñaba como enfermera. En otro lugar del diario describe el coro bajo de la capilla del convento:

\footnotetext{
40 Ibídem: $72-73$.

41 Acosta 2004: 185.

42 Ibídem: 207.

43 ídem.

44 Ibídem: 220.
}

Entramos al coro bajo, que es el lugar donde antes enterraban a las monjas (...) Siempre está aquello lúgubre, oscuro y húmedo. Se separa de la iglesia por una reja doble, una de fierro y otra de madera, y sobre la [reja] que está hacia el interior, un gran velo negro no permite de noche ver la Iglesia. ${ }^{45}$

Describe la iglesia como "solemne y al mismo tiempo tan tenebrosa», ${ }^{46}$ y el rezo de las monjas en la iglesia como un espectáculo lúgubre y casi terrorífico:

Reina una oscuridad profunda en todo el templo, solamente en el altar mayor ardía una lámpara piadosa... Unas veces el mover del viento daba una luz más fuerte e iluminaba las doradas joyas de los altares por toda la iglesia... Después pasaba como sombras y volvía a quedar todo menos el altar mayor en tinieblas... Y la monja rezaba hincada en la mitad de coro cual blanca sombra en actitud devota, y la rodeaban negros bultos contestando la oración. Las voces resonaban en aquel espacio cual eco doloroso y seguía la monja en su melancólica plegaria (...) En la iglesia silenciosa, ya oscura, ya aclarada por sus rayos, ¡la lámpara piadosa, hacía el cuadro cuan triste! (...) Yo no oraba, una especie de pavor me tenía los ojos fijos en el interior de aquel silencioso templo. ${ }^{47}$

Este acontecimiento marcó, sin duda, su vida y sus pensamientos, al punto que años más tarde le mereció un detallado escrito, titulado "La Monja". ${ }^{48}$ En este, lejos de idealizar al convento femenino, lo mostraba como un lugar con sus pequeñas satisfacciones, juegos de poder, desilusiones amorosas, alguna hija ilegítima, hermanos que se habían apoderado del dinero de sus hermanas, ignorancias, curiosidades, sabidurías, resignaciones. En el texto la narradora, supuesta lectora del diario de una joven que por razones políticas había vivido un tiempo refugiada en un convento de clausura (obviamente hablaba de su propio diario) comienza el relato en contra de los conventos y termina defendiéndolos. Concluía, entonces, con una visión matizada de la vida conventual; sin idealizarla, la acepta como una posibilidad de organización social, transmitiéndonos al mismo tiempo su clara visión de la falta de alternativas en la vida de la mujer de su época.

Ciertamente, Soledad en este sentido estaba influida por la corriente liberal que impregnó el siglo XIX, manteniendo un fuerte recelo con respecto a la vida religiosa como opción de vida. Esta actitud podría revelar también rasgos protestantes en su educación, provenientes de su familia materna.

Paradójicamente, Soledad no sabía que su prevención contra la vida conventual femenina iba a llevarla a un conflicto familiar. En 1896 tuvo un fuerte disgusto con Bertilda, su hija mayor. Ella, quien además era poetisa, ${ }^{49}$ decidió, a los cuarenta años de edad, ingresar al convento de la

\footnotetext{
45 Ibídem: 255.

46 Ídem.

47 Ídem.
}

48 "La Monja”, en Acosta de Samper 1988. Este relato lo publicó la autora reiteradamente y en lugares muy relevantes de su producción: apareció por primera vez en 1864 en la prensa, luego en su primer libro Novelas y cuadros de la vida suramericana (1869), y finalmente como parte de su novela Una holandesa en América (por entregas en 1876 y en libro en 1888).

49 Bertilda Samper Acosta es la autora de una "Novena de Aguinaldos" (publicada por primera vez en 1910 y que constituye una adaptación de otra novena del siglo XVIII) que se convirtió en toda una tradición identitaria colombiana en el último siglo. 
Enseñanza; Soledad se opuso a la idea. Bertilda, haciendo caso omiso de los reclamos de su madre, ingresó al claustro, a escondidas, tomando el nombre de María Ignacia. Desde el convento le escribía pidiéndole comprensión, haciéndole ver que su resolución había sido tomada varios años antes. ${ }^{50}$ Al final Soledad tuvo que resignarse, e incluso experimentar, años después los sentimientos de dolor que vislumbró cuando en su juventud visitó por primera vez el cementerio de un convento: en 1910 Bertilda falleció en el claustro y fue sepultada allí.

\section{LIBERALISMO Y MUNDO MODERNO}

Soledad manifestó una actitud ambivalente frente al liberalismo de su tiempo. Por una parte, apoyó el régimen republicano, considerándolo más "civilizado" que cualquier otro, y asumió valores liberales clásicos. Por otra parte, en su edad madura, criticó a ciertos pensadores y políticos liberales por sus actitudes antirreligiosas o anticlericales. Finalmente, siempre manifestó un horror a cualquier forma de socialismo.

En su juventud, época en la cual escribió el diario, se observan manifestaciones de aprecio frente al régimen liberal que se estableció en la década de 1850 . Consideraba de forma positiva la constitución liberal de 1853 y lamentaba el golpe de estado llevado a cabo por el General Melo y las sociedades democráticas de artesanos (autoproclamadas como "socialistas") cuyo régimen siempre criticó y despreció profundamente. ${ }^{51}$ En mayo de 1854 Soledad conmemora el aniversario de la malograda Constitución liberal de 1853 que el régimen de Melo había suprimido en apenas unos meses después de su proclamación..$^{52}$ Esta actitud, por parte de una persona que se declaraba "profundamente religiosa" y católica, debe resaltarse. La constitución de 1853 había consolidado un primer ciclo de reformas iniciado en 1847 tendientes a la modernización del Estado. Sus reformas habían afectado intereses de la institución eclesiástica neogranadina a través de medidas como la supresión del diezmo, la expulsión de los Jesuitas, la supresión del fuero eclesiástico y la separación Iglesia y Estado y la proclamación del matrimonio civil. También había declarado el libre comercio, lo cual ofuscó a los artesanos que se aliaron con los militares para tomarse el poder a la fuerza. A diferencia de muchos clérigos y laicos de su época, que combatían el régimen liberal y que predicaban y escribían periódicos, artículos y libros contra el régimen y las ideas que lo sostenían, Soledad Acosta lo consideraba benéfico para la estabilidad y "progreso" de las gentes de su país.

Más adelante, a raíz de los acontecimientos anticlericales ocurridos entre 1861 y $1863^{53}$ y con el correr del tiempo,

\footnotetext{
50 Samper Trainer: 148.

51 Acosta de Samper 2004: 247.

52 Ibídem: 263.

53 La victoria de Tomás Cipriano de Mosquera en la guerra civil de $1859-1862$, y la proclamación de la Constitución de 1863, conllevaron la implementación de un segundo "ciclo" de reformas en materia político-religiosa. Las más importantes fueron: la expropiación de bienes eclesiásticos de manos muertas, la tuición de cultos (todo sacerdote debía jurar obediencia al gobierno para poder ejercer su ministerio) la supresión de comunidades religiosas de ambos sexos y la expulsión de los jesuitas. Tales medidas generaron una polémica enorme
}

Soledad fue moderando algunas de sus ideas. Sin embargo siempre habría de exponer un liberalismo "a la inglesa" (Soledad denominaba a Inglaterra "el país más civilizado del mundo"54) promocionando en sus revistas valores capitalistas como el trabajo, la productividad, el pragmatismo. Esto, a pesar de sus comentarios en contra de Rousseau, Voltaire y otros pensadores franceses padres del liberalismo político, a quienes Soledad, en su revista La Mujer calificaba de "hipócritas" a quienes se debía desenmascarar para "que no engañen con su pretendido amor al pueblo, al oprimido y al desgraciado». ${ }^{55}$ Más que antiliberal, la de Soledad Acosta tenía ante todo una posición contraria al socialismo y a las doctrinas de corte populista, las cuales siempre vio con miedo y desdén.

La autora, miembro de un grupo privilegiado de la sociedad, material e intelectualmente, integrante de una familia de comerciantes, ${ }^{56}$ se insertaba y estaba de acuerdo con una serie de valores propios de la naciente burguesía, aunque mostraba una gran simpatía por la aristocracia. Observaba a Latinoamérica con el prisma europeo, especialmente inglés. Desde ahí juzgaba la política, la sociedad y la condición de la mujer. Pero al mismo tiempo defendía la particularidad de los americanos y en el Congreso de Americanistas de Huelva, en 1892, se refirió al americano como alguien culturalmente diferente, más no inferior, al europeo y sobre todo, al español, cuya cultura miraba con cierto desprecio, ${ }^{57}$ esto, en plena época hispanófila en Colombia, como fueron los últimos años del siglo XIX y las primeras décadas del XX..$^{58}$ Aunque aceptaba valores fundamentales e innegables del mundo moderno, Soledad se mostraba reticente a las posturas que pretendían ir más allá, especialmente aquellas que procuraban un cambio de estructuras económicas y sociales en favor de los sectores populares, las cuales consideraba poco menos que catastróficas. Por otra parte, supo conciliar estas ideas con su fe católica, aunque no se propuso hacer un ejercicio teórico de conciliación entre el sistema político y el sistema religioso (es decir, no escribió ningún tratado en ese sentido). Esta labor sí fue emprendida por algunos pensadores católicos en distintos lugares del mundo occidental, pero después de 1864, tras la publicación de la encíclica Quanta Qura y del Syllabus, fue considerada casi herética. Soledad simplemente vivió en la práctica esta conciliación y la expresó de forma implícita y natural en sus publicaciones, al punto que nadie dudó de su ortodoxia. ${ }^{59}$

y propiciaron una reacción intransigente, en los años siguientes, de parte del clero tradicionalista y liderada por varios obispos.

54 Acosta de Samper 1878b: 47.

55 Ibídem: 46-47.

56 Gómez Giraldo s. f.

57 Soledad Acosta llegó a plantear la fundación de una Academia de la Lengua Americana, haciendo a un lado a la Real Academia Española, a la que calificaba de arrogante.

58 Véase Figueroa 2009. En estos años se produce en buena parte de las élites colombianas, una revalorización de la lengua y cultura hispánicas, como elementos positivos para la construcción de una identidad nacional.

59 Al fallecer, en plena época de la Hegemonía Conservadora y de un catolicismo intransigente, la Revista del Colegio del Rosario publicó un artículo in memoriam en el cual se dice: «Se ha creído que las mujeres literatas no son cristianas piadosas, ni buenas esposas y madres, ni modelos de honestidad y recato. El ejemplo de la Sra. Soledad Acosta basta para desmentir aquella preocupación insensata», citado en VV. AA. 1914: 51. 


\section{SU ESPOSO "RADICAL"}

El haber contraído matrimonio con un político y periodista, inicialmente miembro de la facción "Gólgota" del partido liberal (futuro "radicalismo"), contribuyó mucho a dicho ejercicio práctico de conciliación entre fe y liberalismo. El diario íntimo de Soledad da muchas pistas para comprender cómo se planteó dicha relación.

Claro es que a José María se le había generado una mala reputación por su activismo anticlerical, su participación en la masonería y su activa promoción de leyes como la expulsión de los jesuitas y el matrimonio civil, entre otras. Esto hizo que, cuando empezó a cortejar a Soledad, doña Carolina Kemble, madre de esta, expresara a su hija las dudas que tenía sobre José María. Soledad escribió una noche de enero de 1854 en su diario: "Mi mamá anoche me dijo que era muy malo, que tenía muy mala reputación y que no debía yo pensar en él!». Para entonces ella estaba ya profundamente enamorada de él y no pensaba dejarlo. Encontró en José María a alguien que se interesaba en ella como intelectual, en lo que ella pensaba; no sólo la veía como una madre para sus hijos, como compañía en el hogar. Soledad era una mujer por encima del promedio, y esto no era naturalmente valorado por los de su entorno, salvo por José María.

Ahora, es claro también que Samper estaba lejos de ser irreligioso. De hecho, su idea de Dios era bastante cercana a la de un cristiano católico ilustrado de hoy día. Era un cristiano que aceptaba a Dios no porque las tradiciones se lo enseñaran, sino porque lo había experimentado, porque lo veía en el universo, en la naturaleza. Soledad menciona en su diario cómo Samper, en un artículo publicado en la prensa, hace una declaración de fe, expresando su idea de Dios y cómo había aprendido a reconocerlo y a quererlo. ${ }^{60}$ En ese sentido se parecía mucho a Soledad, quien en su diario íntimo en más de una ocasión afirmaba reconocer a Dios en la naturaleza, expresándose de forma similar.

Si Samper tenía fama de anticlerical, en el fondo su fe religiosa no se distanciaba mucho de la de Soledad. En su autobiografía escrita en la década de 1870, afirma, sobre esta época, lo siguiente:

Yo creía que el catolicismo practicado por mis compatriotas tenía más de superstición que de fe religiosa, más de paganismo tradicional disimulado que de prácticas verdaderamente cristianas y persuadido así... me parecía de muy buena fe, acto patriotero y laudable el emprender con valor y entereza, desafiando todo peligro, la cruzada por medio de la prensa contra la disciplina de la Iglesia neogranadina. ${ }^{61}$

Sin embargo, prosigue: «Aún en mis tiempos de mayor radicalismo (...) jamás ataqué ningún dogma ni procuré apartar a persona alguna de la fe religiosa». ${ }^{62}$

En febrero de 1855 ante una pregunta que Soledad hizo a José María sobre si la amaría siempre,

Su contestación fue bajar la Biblia de adonde estaba y jurarme sobre ella que me amaría eternamente... ¿ ¿Habéis pensado que después de haber jurado sobre las Santas Escrituras tu amor sería eterno?... yo también te lo juré sobre ese libro fundador del Cristianismo y de la Fe, que te

\footnotetext{
60 Acosta 2004: 147-148

61 Samper 1971: 123.

62 Ídem.
}

amaré eternamente. ¡Nuestro amor es un reflejo del amor divino y ambos lo juramos sobre el 'Libro de los Libros'!. ${ }^{63}$

Ese mismo día escribió: «Pepe [por José María], algunas veces he creído que no eras lo suficientemente respetuoso hacia la Religión del Cristo, lo que me ha dado algún pesar». Y a continuación le explicó a Samper (quien, desde la fecha de su compromiso leía el diario de Soledad) por qué era creyente y cuáles eran los parámetros de su creencia. ${ }^{64}$

Antes de casarse, la víspera, Soledad fue a la Iglesia de San Francisco, se confesó y oró por su matrimonio, ${ }^{65}$ el cual se celebró el 5 de mayo de 1855 en ceremonia presidida por el mismo Arzobispo de Bogotá, Antonio Herrán, quien además fue el padrino de bodas. Esto podría parecer paradójico en un hombre como José María Samper, por sus antecedentes y por haber promovido desde el congreso, dos años antes, la causa del matrimonio civil, bajo el cual él mismo se había unido a su primera (y fallecida) esposa en 1853. Pero, como se dijo, en el fondo José María Samper no rechazaba las creencias católicas; como muchos liberales de su época, era conservador en su vida privada. El liberalismo que exponía era de tipo político y económico, no social. Tampoco estaba en contra de las creencias católicas, ni mucho menos de los sacramentos. Su oposición a la institución eclesiástica, como la de muchos liberales amigos suyos, se basaba en una prevención hacia ciertos sectores del clero caracterizados por su intransigencia y hacia lo que llamamos "religiosidad popular": prácticas y costumbres religiosas de tipo barroco-sincrético que acentuaban ritos y actos exteriores antes que la vivencia de la ética cristiana y en las cuales los grupos populares estaban inmersos. Prácticas con las que Soledad Acosta, la católica, tampoco comulgaba.

Tras un conflicto con un sacerdote intolerante que terminó en golpes y en escándalo público -y que sirvió para comprobar el peso social que tenía el clero- la familia decidió salir de Colombia y radicarse un tiempo en Francia (5 años, entre 1856 y 1861). En este tiempo tanto José María como Soledad reflexionaron sobre las consecuencias de las divisiones políticas y las actitudes intolerantes, las guerras civiles, etc. Al tiempo conversaban sobre sus diferencias religiosas. En su convivencia con las distintas maneras de ver lo religioso y lo político, José María Samper inició una etapa de reflexión sobre las luchas antagónicas y partidistas, sobre cuestiones religiosas. En esta perspectiva, Soledad le hizo ver discretamente, según Samper, que si él adoraba a sus hijas y había consentido que tuvieran una educación católica, su actitud anticlerical terminaría por distanciarlos, puesto que «faltaría uno de los más poderosos vínculos de confianza, de identidad y de unión». ${ }^{66}$

Lo cierto es que tras regresar al país y conforme el régimen liberal radical (1861-1885) se afianzaba, José María Samper fue tomando distancia de las ideas radicales, aunque nunca dejó de ser y considerarse "liberal". ${ }^{67}$ En la

\footnotetext{
63 Acosta de Samper 2004: 502

64 Ibídem: 503.

65 Ibídem: 547-548.

66 Samper 1971: 581.

67 Para Samper el liberalismo era mucho más que pertenecer a un partido político con ese nombre. Significaba una visión de mundo abierta al cambio, a la libertad de opinión, de movimiento y de empresa, a la transformación, a la confianza en el progreso, la razón, la ciencia y en las instituciones republicanas (Plata 2009: 112-113).
} 
década de 1870 se acercó más al catolicismo institucional y llegó a formar parte del grupo gestor de la Regeneración que llevó al fin del régimen radical, a la conformación de un estado centralista y a la reconciliación entre la Iglesia y el Estado. José María Samper, quien desde 1878 engrosó las filas del Partido Conservador, fue uno de los promotores de la Constitución de 1886, ${ }^{68}$ trabajando al lado del presidente Rafael Núñez, otro antiguo radical "converso", como él. ${ }^{69}$

\section{CATEQUESIS Y CARIDAD}

Con el paso del tiempo, a medida que su esposo se reconciliaba con la Iglesia Católica, Soledad fue ahondando más sus vínculos con ella, al punto de llegar a ser lo que ahora se conoce como una "laica comprometida"; esto ocurrió al final del período radical y durante la Regeneración, cuando la Iglesia neogranadina se recomponía y solicitaba al laicado su apoyo en este proceso. Soledad, en su madurez, afirmó que el catolicismo era el mejor sistema para abordar los misterios de la divinidad y explicar sus propósitos para la vida humana. Al tiempo proclamó en sus escritos la necesaria educación religiosa de la mujer: la religión era fundamental en su vida, por eso reclamaba a los legisladores la enseñanza religiosa, pues las mujeres estaban "naturalmente inclinadas" a la religión y esta era la salvaguardia de la sociedad. Una mujer sin religión se convertiría en un ser perverso:

Señores encargados de la educación pública: dudamos que ninguno de vosotros miraría con gusto a una mujer cuyo ejemplo fuese el de las mujeres de París durante la Comuna! Y sin embargo, nuestras mujeres del pueblo serán peores, mil veces peores, porque son menos civilizadas, menos instruidas y más brutales que las parisenses. ${ }^{70}$

Esta faceta se acentuó tras la muerte de su esposo en 1888. Sus publicaciones posteriores adquieren un matiz más religioso que las precedentes. Estamos además en otra época, la Regeneración, momento en la cual la institución eclesiástica consiguió de nuevo el apoyo del Estado, desarrolló su proyecto romanizador, recuperó privilegios y su protagonismo se acentuó. Por entonces hubo un renovado impulso a las publicaciones dirigidas a la mujer y a la familia, considerada esta última como centro, principio y fin de la formación religiosa.

A esta época pertenecen periódicos como El Domingo de la Familia Cristiana (1889-90), fundado y dirigido por Soledad Acosta y del cual surgió más adelante el libro Domingos de la Familia Cristiana (1896) y su siguiente periódico, El Domingo (1898-99). En ellos, Soledad realizó una labor catequética muy original para el momento. En esta revista, publicada semanalmente para ser leída en familia, la autora explicaba el evangelio dominical utilizando para ello la conocida figura de los diálogos en "tardes de

68 La Constitución de 1886 fue un hito en el proceso de conformación del estado nacional colombiano. Estableció un estado centralista, unitario y presidencialista, establece el catolicismo como la "religión de la nación" y se amparó en la Iglesia Católica como sostén del régimen. Estuvo vigente hasta 1991, cuando fue reemplazada por una nueva constitución.

69 Charry Samper 1997

70 Acosta de Samper 1878a: 125. domingo". Tal labor se entiende en la medida que a la mayor parte de la población del país, al vivir en contextos rurales, se le dificultaba mucho asistir a la misa dominical. Aún no hay estudios de fondo, pero nuestras propias investigaciones muestran que la asistencia dominical a la misa era muy difícil para la mayor parte de la población rural (mayoritaria por entonces). Por eso esta labor fue apreciada por los obispos y muchos sacerdotes del país, a juzgar por las cartas que ella afirmaba haber recibido. Así, por ejemplo, un sacerdote lector de su publicación le habría escrito:

Hacía mucho tiempo que deseábamos que hubiera un periódico que sirviese para la lectura en familia los domingos, en el cual se explicara familiarmente el evangelio del día a aquellas personas que no pueden asistir al sermón del párroco, o que, viviendo quizá en el campo, no le es posible ir a la misa. ${ }^{71}$

Otra faceta poco conocida de Soledad fue su papel activo en organizaciones de caridad y beneficencia. A partir de la década de 1860 la Nueva Granada católica asumió con cierto interés un nuevo tipo de organización laical diferente a las tradicionales cofradías y hermandades, para dedicarse a labores asistencialistas, caritativas y catequéticas. La institución eclesiástica neogranadina, debilitada como estaba por las reformas liberales, las guerras civiles y la desaparición de las comunidades religiosas, que otrora atendían labores de beneficencia (como los Hermanos de San Juan de Dios, suprimidos en 1861) decide "echar" mano del laicado. Por eso, durante estos años nacieron organizaciones inéditas que sirvieron para fomentar y diversificar formas de "sociabilidad" (como la llaman algunos autores) ) $^{72}$ entre católicos, contrastando con otras formas de sociabilidad de tipo política - laica (masonería, organizaciones políticas y literarias, sociedades esotéricas, etc.) La primera y más conocida de estas asociaciones es la Sociedad de San Vicente de Paúl, nacida en 1857 y que se mantiene vigente a comienzos del siglo XXI.

Las asociaciones benéficas fueron impulsadas además, debido al crecimiento que empezaron a experimentar algunas ciudades como Bogotá, en medio de continuas crisis económicas generadas por las guerras civiles. Esto aumentó la mendicidad y problemas como el abandono de niños recién nacidos por sus padres. De Bogotá, Miguel Samper, cuñado de Soledad, nos cuenta que,

Los mendigos llenan calles y plazas (...) La mendicidad es un hecho alarmante en más de un aspecto. Pero no todos los mendigos se exhiben en las calles. El mayor número de pobres de la ciudad, que conocemos con el nombre de "vergonzantes", ocultan su miseria, se encierran con sus hijos en habitaciones desmanteladas y sufren en ellas los horrores del hambre y la desnudez. Si se pudiera formar un censo de todas las personas a quienes es aplicable en Bogotá el nombre de vergonzantes (...) el guarismo sería aterrador. ${ }^{73}$

Por eso, la atención a niños expósitos y ancianos, por medio de hospicios y ancianatos, fue otra de las preocupaciones de las asociaciones laicales. Algunos de estos hospicios habían sido creados por el clero, incluso desde tiempos

\footnotetext{
71 Acosta de Samper 1889.

72 Véase Loaiza Cano 2011: 2a parte, cap. 1.

73 Samper 1969: 8-9
} 
coloniales. Sin embargo, tras las reformas de mediados de siglo y las expropiaciones de 1861, fueron cerrados. Las distintas "sociedades" de beneficencia y caridad se encargaron entonces, de reabrirlos o crear nuevos.

Asimismo, se realizaban visitas a familias pobres, previamente censadas, con el fin de conocer sus necesidades materiales y brindarles alguna colaboración económica o en especie. Al principio preferían visitar los llamados "pobres vergonzantes", es decir, aquellas familias que habiendo disfrutado de alguna fortuna, lo habían perdido todo y se encontraban en situación de miseria, pero evitaban a toda costa darla a conocer. Más adelante acudían también a los barrios y sectores marginados de las ciudades, llevando comida, ropa y útiles varios. Para obtener los fondos necesarios, se organizaban rifas y bazares, además de acudir a las casas de personas adineradas para recoger limosnas. A veces, los obispos y algunos sacerdotes aportaban de su propio peculio o de los fondos parroquiales para el sostenimiento, tanto de las casas de beneficencia, como de las familias pobres.

En esta labor fue importante el papel cumplido por las mujeres; y es que a pesar de la fuerte presencia masculina en estas asociaciones, pronto se dio paso libre a la mujer, para que colaborara en ellas, y más en las labores que requerían cierta paciencia y cuidado, como la atención de niños y ancianos, pues no era usual concebir la caridad sin la mujer, fundamentalmente por las cualidades asociadas a ella ("suavidad", "dulzura", "armonía", "mansedumbre", "consuelo") y especialmente, la estabilidad y la persistencia. Una asociación caritativa de la época afirmaba al respecto, que toda obra social que pretendiera permanecer por largo tiempo, debía tener en cuenta a la mujer. ${ }^{74}$

Una de las primeras organizaciones caritativas femeninas se llamó la Congregación de Caridad (1859-1861) y estaba compuesta por señoras de las clases pudientes de la capital, siendo dirigidas por el Vicario General de la arquidiócesis. Entre sus miembros estuvieron mujeres de la alta sociedad bogotana, como Silveria Espinosa de Rendón (escritora), María Francisca Urisarri de Cuervo, Concepción Ibáñez de Francisco y Rita de Francisco, y otras 190 socias.

El ejemplo de esta primera sociedad de beneficencia cundió y pronto surgieron otras asociaciones caritativas femeninas inspiradas en ella. Así, durante la década de 1870 nacieron la Archi-cofraternidad de las madres cristianas y la Sociedad protectora de niños desamparados. Soledad Acosta militó y tuvo liderazgo en ambas organizaciones. Estas tenían como fin primordial el recoger, albergar y educar niños desamparados; muchos de ellos, recién nacidos. ${ }^{75}$ Uno de sus frutos fue la creación del Albergue San Antonio, concluido en 1902. En este propósito, Soledad llegó a vender lotes y propiedades suyas en Guaduas, cuyo dinero donó a la obra.

Este tipo de organizaciones tuvieron mucho protagonismo en la sociedad de entonces y fueron alentadas por el Papa León XIII con su encíclica Rerum Novarum (1891) que legitimó y proyectó la corriente del catolicismo social, la cual tendrá gran protagonismo en el siglo siguiente.

\footnotetext{
74 "Actos del Consejo" en Anales de la Sociedad de Beneficencia y Caridad 1: 22 de agosto de 1882: 6.

75 Acosta de Samper 1878: 118.
}

Así, Soledad Acosta no sólo puso su pluma al servicio de la Iglesia a la cual pertenecía y en la cual creía; también se vinculó a la acción social, motivada desde su fe, y tal como se concebía por entonces. Esta faceta merece ser estudiada y profundizada a partir de nuevas fuentes, y de nuevas lecturas de fuentes disponibles. Lo cierto es que todo ello le generó gran reconocimiento en su época entre el clero, que nunca dudó de su ortodoxia, considerándola como una de las hijas más "ilustres" de la Iglesia. Algo que puede verse en la multitud de elogios que, tras su fallecimiento, Soledad recibió por parte de eclesiásticos y personas vinculadas activamente con la Institución eclesiástica.

\section{CONCLUSIÓN}

Este artículo quiso presentar la faceta creyente y religiosa de Soledad, que, aunque vinculada a su tiempo y a su contexto, sobresalía por su particularidad y sus logros. Vemos en ella la presencia de un nuevo tipo de catolicismo. Junto al catolicismo tradicionalista, propio de quienes añoraban los "buenos tiempos" que para la Iglesia había representado la sociedad colonial, existía una corriente que, defendiendo el cristianismo y el rol de la Iglesia en la sociedad, se adaptaba a las nuevas ideas y dinámicas que proponía la naciente sociedad moderna. Soledad fue una de las pioneras en la expresión de este nuevo catolicismo de "conciliación", de vanguardia, que buscaba un diálogo entre la fe y la Iglesia Católica con algunos principios fundamentales del mundo moderno. Dicha corriente permeaba sectores ilustrados del catolicismo en todo el mundo y se expresó de diversas formas, algunas de las cuales recibieron fuerte rechazo por parte de la institución eclesiástica a medida que la confrontación Iglesia-liberalismo e Iglesia-Mundo moderno subía de tono. ${ }^{76}$ Soledad pudo llegar a pensar y vivir de esta forma, dada su particular situación familiar y su condición de mujer de letras, cosmopolita y viajera. Soledad tuvo contacto con personajes de vanguardia de la época en Europa occidental, vivió en su seno familiar el conflicto protestantismo-catolicismo-mundo moderno, y tomó decisiones en ese sentido. Conoció, por otra parte, en qué tipo de Iglesia se encontraba, cuáles eran sus grandes problemas, sus defectos y aprendió a aceptarla así y a quererla. Tomó, sin embargo, distancia de un clero al cual calificaba, con razón, de poco ilustrado, obviamente sin llegar a confrontar abiertamente con él, pues sabía cuál era su poder, y tenía claros sus propios límites como mujer en esta época y contexto.

Por otra parte, su espíritu inquieto, abierto a los nuevos tiempos, buscó a alguien que le ayudara a caminar en las nuevas sendas que señalaban los cambios. Y halló a una persona también singular, a alguien que, aunque creyente como ella, había decidido acudir a las armas de la política para tratar de apurar cambios que consideraba necesarios, cambios que evidentemente le generaban conflictos y enemigos otorgándole "mala reputación" entre los conservadores y clérigos tradicionalistas. Las distintas dificultades que la pareja tuvo que afrontar, entre otras razones, por las confrontaciones políticas y las guerras civiles, llevaron a comprender la necesidad de ser más sutil si buscaba procurar

\footnotetext{
76 Bénichou 1984: 67 y ss.
} 
transformaciones; la sociedad en que vivían era demasiado intolerante y tradicionalista.

Ya en el cenit de su vida, Soledad emprendió una labor que combinaba la promoción de un nuevo tipo de mujer y de su rol para la sociedad,,$^{77}$ con la formación religiosa de la mujer y de su familia. Para ello se sirvió de la prensa como instrumento fundamental, como órgano comunicativo por excelencia de la modernidad, adoptando sus reglas: la dinámica de la modernidad implicaba entrar en el debate público de ideas con otros grupos, varios de ellos opuestos entre sí, y demostrar que sus tesis y consignas eran las más apropiadas para la sociedad del momento y los tiempos que corrían, tal como lo hizo la institución eclesiástica decimonónica con la prensa. Según afirma Claudia Castillo:

Promover la prensa católica era reconocer, más o menos conscientemente, que se estaba en una nueva sociedad. Sus promotores aceptaron las reglas de un universo plural, o bien, en vías de su consolidación, y su sola presencia ayudó al fortalecimiento de la esfera pública, además del forjamiento del catolicismo como gestor de una opinión y una postura frente al mundo. Como una más, entre otras y con otras. Y el catolicismo hablando desde un lugar muy distinto del que lo había hecho antes. Ya no bastaba, por un lado, el púlpito y las prédicas. ${ }^{78}$

Soledad se inscribe en la nueva dinámica al integrar y liderar nuevas organizaciones socio-religiosas donde el rol del laico y de la mujer laica, asumía dimensiones protagónicas, a pesar del clericalismo dominante, pero facilitado por la crisis institucional que vivía la institución eclesiástica católica. Las asociaciones de beneficencia y caridad en las cuales militó Soledad se convierten en la punta de lanza de un nuevo proyecto social de la Iglesia Católica que buscaba, con propuestas de este tipo, responder a los desafíos que le planteaban el liberalismo, el capitalismo y la sociedad moderna con sus múltiples problemas directos y colaterales.

El catolicismo, pues, se fue definiendo como un ente diferenciado por medio de la educación religiosa y la difusión de los valores cristianos a través de la prensa, la promoción de nuevas formas de organización laical y la lucha contra los intentos de laicización del estado y de la sociedad. La Iglesia se definía como actor diferente del Estado, del partido, de la escuela, estableciendo su propia actividad, su campo de acción, sus miembros y hasta su público, elementos todos estos propios de la dinámica de la modernidad. ${ }^{79}$ En relativamente poco tiempo se fue difuminando aquella sociedad en la cual las fronteras entre lo público y lo privado, la Iglesia y el Estado, lo religioso y laico no estaban definidas, transformándose en una sociedad en donde se discutía sobre el rol de la Iglesia en lo "público" y hasta dónde debía influir el clero. Se trazaban distancias entre el Estado y la Iglesia: el primero renunciaba a regir a la segunda, garantizándole su "independencia", y se hacían pactos en torno a proyectos de sociedad y de estado acordes a los intereses de los actores del momento, según los cuales cada uno guardaba su lugar y actuaba como ente diferenciado y autónomo. Así, se conformaba una nueva dinámica político-religiosa a la cual Soledad Acosta aportó mucho más que un grano de arena.

77 Algunas obras que estudian estos aspectos en la obra de Soledad Acosta son: Hincapié 2007; Segura 2010 y Licon 2014.

78 Castillo 2008: 841-842.

79 Ibídem: 843.
Una última observación tiene que ver con la evolución del pensamiento religioso a lo largo de la vida de Soledad Acosta. Vimos una continuidad en el mismo; sus posiciones no cambiaron mucho, aunque, ciertamente, en la etapa madura de Soledad, la vimos mucho más próxima y comprometida con la institución eclesiástica, evitando entrar en conflicto con ella. De modo que varias de las posiciones de su juventud (por ejemplo, respecto al clero de su patria) jamás fueron expresadas públicamente en sus obras, prefiriendo la prudencia. En lo que respecta a otras ideas, como su visión frente a los conventos femeninos y masculinos, no guardó silencio. Pero ciertamente, Soledad prefirió proponer, antes de que controvertir. Sabía que no ganaría nada y sí perdería mucho al entrar en disputas de esta índole en un contexto marcado por la intransigencia político-religiosa.

Lo expuesto aquí sobre la visión religiosa de Soledad Acosta de Samper, -lo que consideramos un abre-bocas para un estudio más completo- es un aporte a la propuesta de revisión de la historia del catolicismo latinoamericano en el siglo XIX, propuesta por autores como Ana María Bidegain, ${ }^{80}$ Manuel Ceballos, ${ }^{81}$ Fortunato Mallimaci ${ }^{82}$ y Aldo Almegeiras, ${ }^{83}$ entre otros. Y que lo concibe como un sistema dinámico y diverso, compuesto por corrientes, fruto de las relaciones e interpretaciones que los creyentes hacen entre su fe y los procesos políticos, sociales y económicos de su tiempo. Para ahondar en esta perspectiva los estudios biográficos son determinantes, pues permiten observar ciertos detalles ligados a la evolución y desarrollo del pensamiento religioso y político-religioso, con sus contradicciones, conflictos, logros y adaptaciones. En Colombia, este trabajo aún se encuentra en estado embrionario.

\section{BiBLIOGRAFÍA}

Acosta de Samper, S. 1878a. «Instrucción pública en Cundinamarca». La Mujer 6.

Acosta de Samper, S. 1878b. «Revista de Europa». La Mujer 2.

Acosta de Samper, S. 1889. "A nuestros lectores». El domingo de la Familia Cristiana 1: 1

Acosta de Samper, S. 1988 Una nueva lectura. Edición de Montserrat Ordóñez. Bogotá: Fondo Cultural Cafetero.

Acosta de Samper, S. 2001. "Bogotá en el año 2000: una pesadilla». Revista de Estudios Sociales, 5: 117-123.

Acosta de Samper, S. 2004. Diario íntimo y otros escritos de Soledad Acosta de Samper. Edición, introducción y notas de C. Alzate. Bogotá: Instituto Distrital de Cultura y Turismo.

"Actos del Consejo» 1882. Anales de la Sociedad de Beneficencia y Caridad 1. Bogotá.

Almegeiras, A. 2008. "Catolicismo y pluralidad religiosa o pluralidad de catolicismos», en F. Mallimaci (comp.) Modernidad, religión y memoria. Buenos Aires: Colihue

Aristizabal, M. 2005. «La Iglesia y la Familia: Espacios Significativos de Educación de las Mujeres en el Siglo XIX». Convergencia. Revista de Ciencias Sociales 12, 37, 2005: 169-216.

Aubert, R. 1974. Pio IX y su época. Barcelona: EDICEP

Bénichou, P. 1984. El tiempo de los profetas. Doctrinas de la época Romántica. México: FCE.

\footnotetext{
80 Bidegain 2004.

81 Ceballos 1991.

82 Mallimaci 1993.

83 Almegeiras 2008.
} 
Bermúdez, S. 1993. El bello sexo. La mujer y la familia en el Olimpo Radical. Bogotá: Ediciones Uniandes.

Bidegain, A. M. 2004. Historia del cristianismo en Colombia: corrientes y diversidad. Bogotá: Taurus.

Castillo, C. 2008. "La fe en hojas de a centavo. Prensa católica en Chile, sus lectores y el caso de El Mensajero del Pueblo, 1870-1876». Teología y Vida, 49, 4: 837-874.

Ceballos, M. 1991. El catolicismo social: un tercero en discordia: Rerum novarum, la "cuestión social" y la movilización de los católicos mexicanos, 1891-1911. México: El Colegio

Charry Samper, H. 1997. "José María Samper». El Tiempo, 28 de agosto. [En línea] http://www.eltiempo.com/archivo/documento/ MAM-609301 Consultado en septiembre de 2013.

Corpas de Posada, I. 2010. "Los escritos religiosos de Soledad Acosta de Samper: Nuevos apuntes para una relectura de su vida y su obra», en Memorias del XV Congreso Colombiano de Historia. Bogotá, 26-30 de julio de 2010. Bogotá: Asociación Colombiana de Historiadores, 2010 [cd rom]

Corpas de Posada, I. 2013. «Escritos religiosos de Soledad Acosta de Samper (1833-1913): Lectura teológica y en perspectiva de género". Revista de estudios colombianos 43: 22-33.

Figueroa, H. 2009. Tradicionalismo, hispanismo y corporativismo. Una aproximación a las relaciones non sanctas entre religión y política. Bogotá: Universidad San Buenaventura.

Gómez Giraldo L. s. f. «Miguel Samper». Biblioteca Virtual Biblioteca Luis Ángel Arango. [En línea] http://www.banrepcultural.org/blaavirtual/biografias/sampmigu.htm, consultado en julio de 2013.

Hincapié, L. M. 2007 «Moralizadora, cristianizadora y trasgresora: una mirada a la imagen de la mujer en dos textos de Soledad Acosta de Samper». Revista Logos, 11: 81-90

Javaloy, F. 1984. Introducción al estudio del fanatismo. Barcelona: Edicions Universitat de Barcelona.

Licon, Z. 2014. «La educación femenina como proyecto político. Los artículos morales en La Mujer», en C. E. Acosta (ed.) La Mujer (1878-1881) de Soledad Acosta de Samper. Periodismo, historia, literatura: 28-53. Bogotá: Publicaciones del Instituto Caro y Cuervo
Loaiza Cano, G, 2011. Sociabilidad, religión y política en la definición de la Nación. Colombia, 1820-1886. Bogotá: Universidad Externado de Colombia.

Londoño, P. 2004. Religión, cultura y sociedad en Colombia. Medellín y Antioquia. 1850-1930. Bogotá: Fondo de Cultura Económica.

Mallimaci, F. 1993. «Religión, modernidad y catolicismo integral en Argentina». Perfiles Latinoamericanos 2: 105-131.

Plata Quezada, W. 2009 «El catolicismo liberal (o liberalismo católico) en Colombia decimonónica». Franciscanum LI, 152: 71-132.

Plata Quezada, W. 2012. Vida y muerte de un convento. Dominicos y sociedad en Colombia. Siglos XVI-XIX. Salamanca: San Esteban.

Rico Pavés, J, 2006. Los sacramentos de la iniciación cristiana: introducción teológica a los sacramentos del Bautismo, Confirmación y Eucaristía. Colección Manuales Teología Sistemática. Madrid: Instituto Teológico San Ildefonso.

Rodríguez, J. 2004. «Primeros intentos de establecimiento del protestantismo en Colombia», en A. M. Bidegain (ed.), Historia del cristianismo en Colombia. Corrientes y diversidad. Bogotá: Taurus.

Samper, J. M. 1971. Historia de un alma. Medellín: Bedout.

Samper, J. M. 1873. Los partidos políticos en Colombia. Bogotá: Imprenta de Echavarría Hermanos.

Samper, M. 1969 [1867]. La Miseria en Bogotá y otros escritos. Bogotá: Universidad Nacional de Colombia.

Samper Trainer, S. 1995. «Soledad Acosta de Samper», en M. Velásquez Toro (dir.), Las mujeres en la historia de Colombia. Tomo I: Mujeres, historia y política: 132-155. Bogotá: Consejería Presidencial para la Política Social.

Segura, P. A. 2010. El ideal femenino de Soledad Acosta de Samper. Un análisis de los "Estudios históricos sobre la mujer en la civilización" de la revista La mujer. Trabajo de grado (Estudios literarios). Bogotá: Pontificia Universidad Javeriana, Departamento de Literatura. [en línea] consultado el 30 de enero de 2016.

Vargas Martínez, G. 1972. Colombia 1854: Melo, los artesanos y el socialismo. La dictadura democrático-artesanal de 1854, expresión del socialismo utópico en Colombia. Medellín: Oveja Negra.

VV. AA. 1914. Soledad Acosta de Samper. Recuerdos y homenajes a su memoria. Bogotá, Arboleda \& Valencia. 